\title{
Accessibility and Connectivity Measurement on the Quality of Integrated Transportation Services in Sudirman During Pandemic
}

\author{
Rr. Endang Wahyun Deslida Saidah \\ Trisakti Institute of Transportation and Logistics
}

\begin{abstract}
Jakarta, as the capital city of Indonesia, needs an Integrated Transportation to reduce traffic and pollution for a better and healthier quality of life. Integrated Transportation is needed to change people's mindsets and lifestyles, especially during the COVID-19 pandemic. The purpose of this study was to determine and analyze the accessibility and connectivity of Integrated Transportation Services' quality during the COVID-19 pandemic in Sudirman. This research used quantitative methods with multiple regression analysis techniques. The population consists of KRL, MRT, and TransJakarta passengers, while the sample is taken from passengers using the nonprobability sampling technique by means of convenience sampling amounted to 115 . The results showed that the accessibility and connectivity on the quality of Integrated Transportation services during the COVID-19 pandemic had a moderate and significant effect.
\end{abstract}

Keywords: accessibility, connectivity, integrated transportation, COVID-19 pandemic

DOI: $10.7176 / \mathrm{PPAR} / 11-5-03$

Publication date:June $30^{\text {th }} 2021$

\section{Introduction}

Indonesia is one of the countries experiencing the COVID-19 pandemic which was detected in early January and March 2020, spreading rapidly and expanding throughout the provinces.

Before the Large-Scale Social Restrictions (Pembatasan Sosial Berskala Besar - PSBB) occurred, traffic jams occurrs every day in the Capital City due to the large number of Jabodetabek citizens prefers to use private vehicles so that they could reach their destination more easily. In overcoming the traffic in DKI Jakarta, the Government should be more concerned and creative, not only in preparing an integrated mode of transportation but also changing the culture of the citizens who think exclusivism, by forming a mindset and lifestyle towards integrated public transportation that is more comfortable, safer and safer.

A lot of public transportation is now able to integrate in DKI Jakarta. The existence of public transportation, such as buses, microbuses, TransJakarta, train (KRL), LRT, MRT, as well as safe and comfortable facilities and infrastructures are expected to reduce the dependence of people who are using private vehicles changing their lifestyle so that they prefer public transportation. By mass transportation, it is expected that: 1) The environment is clean because it is free from air pollution; 2) Save energy or resources; 3) Minimizing the level of noise and traffic caused by private vehicles; 4) The citizens' quality of life is getting better and healthier because the level of stress and depression has decreased and pollution has been reduced.

The Jabodetabek (Jakarta, Bogor, Tangerang, Bekasi) citizens in carrying out their trips or activities before the COVID-19 pandemic has always use integrated transportation or public transportation, so that during the COVID-19 pandemic they switched to private vehicles due to health protocols and concerns of being contracted. But for people who do not have private vehicles to travel or do their activities, they prefer to use integrated transportation such as KRL, TransJakarta or MRT because the travel time is faster and it has more carrying capacity. Therefore, the Governor of DKI Jakarta, Anies Baswedan, took action to prevent the spread of the corona virus in October, by implementing a policy to carry out the PSBB as in April 2020. This policy was implemented because the death rate due to COVID-19 increase sharply.

This integrated transportation is in great demand by the citizens, especially during the COVID-19 pandemic because it makes it easier for people to switch or exchange to another transportation (interchange) to get to their destination, especially in city centers such as Sudirman. Integrated transportation in Sudirman has several shortcomings in making the interchanges, namely the less convenient and safe accessibility at the exchange locations between transportations, which hinders passenger travel. In its connectivity, namely in the form of an integrated transportation schedule, is not well connected so that travel time becomes long and interferes with passenger activities. In addition, there is also no one integrated ticket for all land transportation completed with its ineffective ticket refilling. Therefore integrated transportation in Sudirman, Jakarta is becoming inefficient and ineffective. The purpose of this study was to determine and analyze the accessibility and connectivity of the integrated transportation services' quality during the COVID-19 pandemic in Sudirman. 


\section{Literature review}

Research of Chairi, Yossyafra, \& Putri (2017) said the idea of multimodal public transportation consists of: 1) Connecting Modes; 2) Main Modes; 3) Multimodal Network (Main Route, Feeder Route); 4) Transfer Point Facility; 5) Mode Transfer Facility with Different Networks (Intermodal Transfer Point); 6) Guidelines and Laws .

Accessibility in transportation is having simple or potential entry access to stations especially from the transportation network framework and the road network framework. The closer the station is to the essential transport network framework, the better the entrance. Meanwhile, Connectivity, namely the association of one mode of transportation with different modes of transportation, makes it easier for passengers (Kuswati, 2012). This accessibility and connectivity are important in integrated transport as it is an easy way to organize the network and association of transport modes with each other. Service Quality is a dynamic condition that is explicitly identified with products / services, human capital, and cycles and climate which in any case can meet or even exceed expectations of service quality (Tjiptono Fandy, 2011).

Accessibility in Transportation is having simple or potential entry access to stations, the framework of transportation network, and framework of the road network. The closer the station is to the important transportation network, the better the entrance. Meanwhile, Connectivity is the association of one mode of transportation with different modes of transportation, makes it easier for passengers (Kuswati, 2012). This accessibility and connectivity are important in integrated transport as it is an easy way to organize the network and associate the transport modes with each other.

Service quality is a dynamic condition that is explicitly identified with products or services, human capital, also cycles and climate which in any case can meet or even exceed expectations of service quality (Tjiptono Fandy, 2011).

\section{Research Methods}

The research method used in this research is quantitative method. The population in this study were users of mass transportation using convenience sampling, which as many as 115 . This study uses Validity Test and Reliable Test. Data collection techniques consist of questionnaires distributed via google form, observation, documentation, and library research. The data analysis technique used are multiple linear regression analysis technique, classical assumption test, normality test, multicollinearity test, heteroscedasticity test, simple correlation and multiple correlation, determination coefficient analysis and hypothesis testing.

\section{Results and Discussion}

Characteristics of the respondents in this study consist of:

1) Most respondents aged 17-25 y.o. by 69 persons (60\%) and the fewest are those older than 56 y.o. by 6 persons $(5.2 \%)$

2) Most of the respondent's occupation is student by 57 persons (49.6\%) and the fewest is "others" by 14 persons $(12.2 \%)$. The number of respondents who filled the questionnaire were a lot of college students and less "others" because during the COVID-19 pandemic, many people did Work from Home (WFH) for their activities;

3) As in gender, large number of respondents were women as many as 58 persons $(54.4 \%)$ and men as many as 57 persons $(49.6 \%)$;

4) Vehicles mostly used during activities from Monday to Friday during the COVID-19 pandemic are private motorbikes by 64 persons $(55.7 \%)$ and only 17 persons (14.8\%) uses microbus. With the COVID-19 pandemic, many respondents chose motorbikes because they are effective and efficient, while those who choses private cars are because many respondents feel more comfortable and safer due to the COVID-19 pandemic and health protocols;

5) Most income of the respondents is less than Rp 2,000,000 per month by 50 persons (45.5\%) and the fewest is within value of $\operatorname{Rp} 2,100,00$ - $\operatorname{Rp~3,000,000~per~month~as~many~as~} 8$ persons $(7.3 \%)$;

6) The travel cost for daily routine activities (Monday-Friday) during the COVID-19 pandemic in a month is less than Rp 500,000 with 55 persons (48,7\%) and the fewest are Rp 2,501,000 - Rp 3,500,000 and more

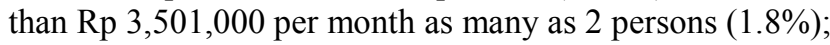

7) The objective of the respondents' movement mostly is to work as many as 57 persons $(49.6 \%)$ and the fewest was "other" as many as 13 persons (11.3\%). In carrying out activities, most respondents were working and studying because during the COVID-19 pandemic other activities were closed.

By looking at the characteristics of respondents during the COVID-19 pandemic, it can be seen that many people use motorbikes because travel time is shorter and can reduce travel costs. Public transportation or Integrated Transportation has not been optimal during COVID-19 in Jakarta and other cities surroundings. The results of this study are supported by the opinion of the Chairperson of the Jakarta City Transportation Council (DKTKJ), Iskandar Abubakar, that there are two principal steps that must be taken so that individuals must leave 
their private vehicles and switch to using public transportation.(Sari, 2017)

The use of Integrated Transportation shows on the results of Respondent Vehicles which during the COVID-19 pandemic has the least respondents. This research is in line with what was said by the Minister of Transportation, Budi Karya Sumadi, in electronic media, saying that a good combination between modes of transportation will make it easier for individuals to use public transportation (Irianto, 2019). During the COVID19 pandemic, it was seen that many respondents tried to avoid using Integrated Transportation because of their concerns about the COVID-19 pandemic and also maintaining health protocols in crowded and public places.

Based on the validity test of all questionnaire statements on the effect of Accessibility variable, it is seen that there are no invalid statements because they have a Corrected Item Total Correlations value of more than 0.1541 ( $>0.1541)$, so that the 5 statements in Accessibility are eligible for analysis by being declared valid, because the $r_{\text {count }}$ starts from the lowest to the the highest are 0.251 to 0.629 larger than the $r_{\text {table }}$ which is 0.1541 .

Moreover, based on the validity test of the three questionnaire statements on the effect of Connectivity variable, it seems that there are no invalid statements because it has a Corrected Item Total Correlations value of more than $0.1541(>0.1541)$, so it is feasible to be analyzed because the $r_{\text {count }}$ starts from the lowest to the highest are 0.386 to 0.498 larger than $\mathrm{r}_{\text {tabel }}$, which is 0.1541 .

Last, based on the results of the validity test of all questionnaire statements regarding the effect of Service Quality variable, there are no invalid statements because it has Corrected Item Total Correlations value more than 0.1541 ( $>0.1541)$, so that the four statements are eligible to use for analysing Service Quality (Y) because they are all valid, showing $r_{\text {count }}$ starting with the lowest to the highest are 0.510 to 0.711 larger than $r_{\text {table }}$ amounted 0.1541 .

The results of the reliability test on accessibility shows that all statement items in the questionnaire have item-total reliability statistics-Cronbach Alpha of $0.693>0.1541$, so the statement is said to be reliable. Connectivity reliability test results are marked by all statement items in the questionnaire have items-total reliability statistics- Cronbach Alpha of $0.640>0.1541$, so the statement is reliable. And, the results of the reliable test on Service Quality show that all statement items in the questionnaire have item-total reliability statistics- Cronbach Alpha of $0.822>0.1541$ so that they become reliable. From the results of the reliable test, the alpha coefficient value is greater than 0.6 , so it can be said that the questionnaire in this study can be declared as reliable.

The classic assumption test for regression normality of the Accessibility and Connectivity variables towards Service Quality during COVID-19, the points spread around the diagonal line, and the spread follows and approaches the diagonal line. In the Multicoloneality Test, Accessibility and Connectivity has value of $0.564>$ 0.10. Meanwhile, the value of Variance Inflation Factor (VIF) on Accessibility and Connectivity is $1.773<$ 10.00 , so there is no multicollinearity symptom in the regression model. From the multicollinearity test results above, the VIF value is below 10 and the tolerance value is above 0.1 . Thus, it can be said that the regression model used do not have multicollinearity problems.

According to the output of the Scatter Plot during the COVID-19 pandemic, it can be seen: 1) The focus of information is spread above and below or around $0 ; 2$ ) The dots do not just converge at the top or bottom; 3) The focus of delivering information does not frame the wavy examples which add to the point boundary and are enlarged again; 4) The focus of the scattered information is not patterned. Based on the results of the heteroscedasticity test, it shows that the regression model has no symptoms of heteroscedasticity, which means that there is no interference.

Based on the correlation coefficient, accessibility has a moderate effect with the correlation coefficient value of 0.488 being in the same positive direction. The increasement that experienced by accessibility will be accompanied by the increasement of Service Quality.

In this study, accessibility has a moderate effect during the COVID-19 pandemic due to the New Normal policy in public transportation which reduces passenger capacity for all transportation by 50 percent and results in the accumulation of passengers at bus stops and stations. This can be seen from the long queues at the Commuter, MRT and Transjakarta so that the waiting time for passengers during peak times, such as morning and evening, can reach 15-30 minutes or even 1 hour. This research is in line with research (Laurentia A.N \& Syafi' $i, 2013$ ) that states Time has the best coefficient value among different factors. Time has a negative coefficient value, which implies that the longer the travel time, the lower the utility value.

According to the results of field observations, Accessibility of Integrated Transportation, namely the distance of movement or interchange between Commuter, MRT and TransJakarta in Sudirman, is less effective because of the long distance between Integrated Transportation that hinders passenger travel and accumulation of passengers that entering or exiting the stops or stations while waiting for their vehicle to arrives due to the capacity reduced by 50 percent also the schedule reduced according to the new normal rules.

Accessibility between Integrated Transportation is very important in improving the quality of transportation services in Sudirman. For example, the pedestrian access, that in fact the distance is far so when the passengers need to change over other transportation, they have to walk quite far and also it is not in the same building so 
that it will be difficult for female passengers especially those who carries children, elders, and people with disabilities. This research is in accordance with previous statement (Rosada, Purnomo, \& Rahma, 2017), that said there is an absence of pedestrian facilities that pass vehicle access such as zebra crossing, absence of transportation access modes that are protected from different weathers including heat and heavy rain, and the station entrance for disembarking passengers from private vehicles causes disputes between public transport and private vehicles. Supported by other research (Andriani, 2018), that said that the most important factor of service improvements are road access and shuttle or guide mode for passengers with special needs to reach other transportation.

For the accessibility in Sudirman, such as the condition of the sidewalks and the width of the road, it is quite comfortable in between Integrated Transportation. However, the unsustainability of sidewalks between Integrated Transportation reduces its comfort. There is a lack of parking and stopping areas for vehicles, especially for public transportation such as online transportation for passengers drop offs and pick-ups, causing the exchange between transportation becomes quite far in distance. Also, there is no one card yet, making it inconvenient for passengers able to access Integrated Transportation access.

Based on the coefficient table, the $\mathrm{T}_{\text {count }}$ value has been obtained, which is 3.025. The value of $\mathrm{T}_{\text {table }}$ is

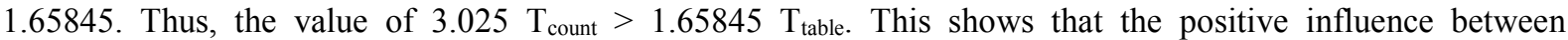
accessibility on service quality is significant or statistically significant. Based on the results of this test, the first research hypothesis $\left(\mathrm{H}_{1}\right)$ which states that there is an effect of accessibility on service quality in Sudirman, Jakarta can be accepted.

Next, based on the correlation coefficient, connectivity also has a moderate effect, with a value of 0.533 which in the same positive direction. The increase that experienced by each Connectivity variable will be accompanied by the increase of Service Quality.

The effect of connectivity during the COVID-19 pandemic shows a moderate effect on service quality. Integrated Transportation connectivity in Sudirman during the COVID-19 pandemic underwent changes in accordance with the new normal rules and health protocols so that network connectivity between Integrated Transportation is still connected. The total service frequency is reduced in Sudirman, so when passengers move from one Integrated Transportation to other Integrated Transportation sometimes it is not connected.

Based on the coefficient table, the $\mathrm{T}_{\text {count }}$ value is 3.596 and the $\mathrm{T}_{\text {table }}$ value is 1.65845 , meaning the $\mathrm{T}_{\text {count }}$ value is 3.596 greater than $\mathrm{T}_{\text {table }} 1.65845$, so Ho is rejected and $\mathrm{Ha}$ is accepted. This shows that the positive influence between connectivity on service quality is significant or statistically significant. Based on the results of this test, the second research hypothesis $\left(\mathrm{H}_{2}\right)$ which states that there is an effect of connectivity on service quality in Sudirman, Jakarta can be accepted.

From the results of multiple linear regression analysis, it can be obtained that the effect of accessibility and connectivity on service quality in this study is mutually influential on the service quality of Integrated Transportation in Sudirman where the accessibility value is 0.239 and connectivity value is 0.560 with the assumption that other independent variables are fixed.

Table 1. Coefficient of Determination

Model Summary

\begin{tabular}{ccccc}
\hline Model & $\mathrm{R}$ & R Square & Adjusted R Square & Std. Error of the Estimate \\
\hline 1 & $.563 \mathrm{a}$ & .317 & .305 & 2.470 \\
\hline
\end{tabular}

a. Predictors: (Constant), Covid Accessibility, Covid Connectivity

Source: compiled by the author with SPSS

Shown on the table above, the coefficient of determination is 0.563 , so it can be interpreted that the effect of accessibility and connectivity on Service Quality (Y) is $56.3 \%$, with the remaining $43.7 \%$ and adjusted R square value of 0.317 . The effect of accessibility and connectivity on the quality of integrated transportation services in this study is the schedule, network, and land use. And other factors that were not examined in this study. The results of this study are supported by previous research (Ramadan \& Buchori, 2018) which states that the improvement of the integrated transportation services quality can be done by developing an integrated strategy for the public transportation system.

From this strategy, it will be known the priority order of handling each variable type of public transportation system integration, namely (1) integration of schedules, (2) integration of networks, (3) integration of land use, (4) physical integration, (5) integration of information, (6) Social integration, (7) Environmental integration, and (8) Integration of fares and tickets. Handling out on the integration of schedules, networks, land use, physical, and information done by improving its performance because the level of satisfaction obtained is still low. While handling out integration of social, environmental, and fares and tickets done by maintaining its performance because the level of satisfaction obtained is already high.

The amount of influence can be seen from the significance value and $F_{\text {table }}$ with the testing criteria that obtained the degree of freedom for this study are 2 for $\mathrm{df} 1$ and 112 for $\mathrm{df} 2$, it can be seen that the value of $\mathrm{F}_{\text {table }}$ in this study is 3.08 (Table f Junaidi). 
Tabel 2. F Test Results

\begin{tabular}{ccccccc}
\hline & Model & Sum of Squares & df & Mean Square & F & Sig. \\
\hline \multirow{2}{*}{1} & Regression & 317,764 & 2 & 158,882 & 26,043 & $.000 \mathrm{~b}$ \\
& Residual & 683,279 & 112 & 6,101 & & \\
& Total & 1001,043 & 114 & & & \\
\hline
\end{tabular}

a. Dependent Variable: Service Quality.Covid

b. Predictors: (Constant), CONNECTIVITY.Covid, AKSEBILITY.Covid

Source: compiled by the author with SPSS

According to the results of the F-test, there is a positive and significant influence between accessibility and connectivitysimultaneously on service quality.

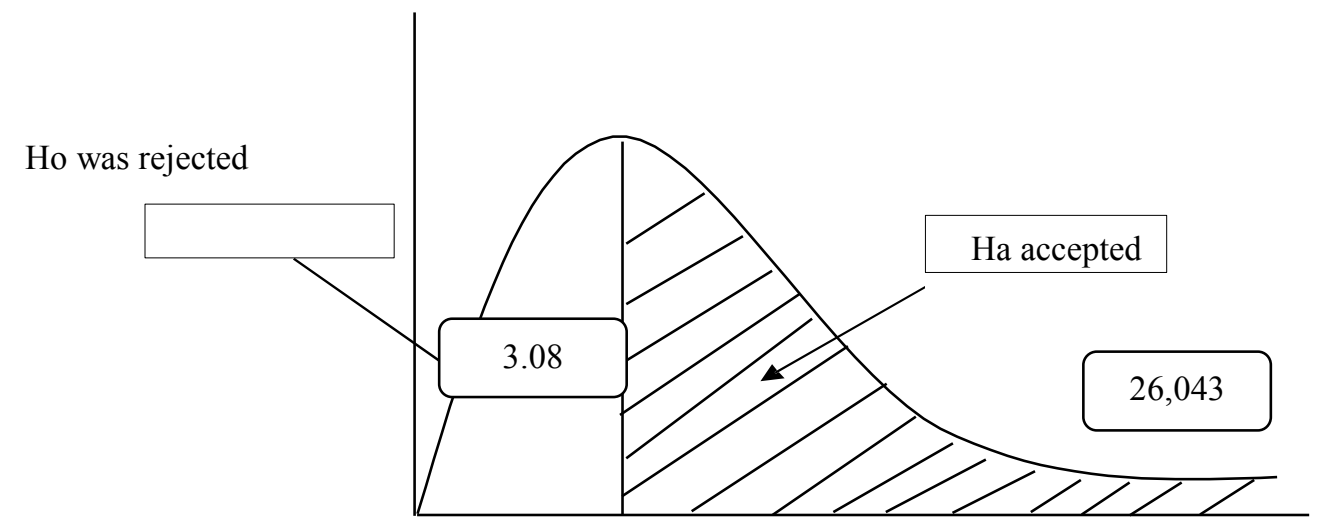

Source: compiled by the author

Figure 1. Distribution Curve

From the curve above, Accessibility and Connectivity simultaneously have a significant and positive effect on the Quality of Integrated Transportation Services in Sudirman with $0.000<0.05$ and the $F_{\text {count }}$ value is 26.04 $3>3.08$. Based on the results of this test, the third research hypothesis $\left(\mathrm{H}_{3}\right)$ which states that there is an effect of accessibility and service quality on the quality of the Integrated Transportation Service in Sudirman is accepted.

\section{Conclusion}

Effect of Accessibility on Service Quality During the COVID-19 pandemic is moderate at 0.488 due to the existence of health protocols, such as a limitation of transportation capacity, reduces passenger capacity for all transportation by 50 percent and results in the queueing of passengers at bus stops and stations was very long causing longer waiting times and a number Integrated Transportation schedule canceled or reduced. The results of the lowest recapitulation on Accessibility during the COVID-19 pandemic in the statement of Proximity, namely the distance from public transportation stops from the house is very close, the suggestion is to add more mass transit stops.

The Effect of Connectivity on Service Quality During the COVID-19 pandemic is moderate with value of 0.533 , this because the number of arrival frequencies of Integrated Transportation is reduced in Sudirman so that when passengers move from one Integrated Transportation to other Integrated Transportation, sometimes it is not well connected. It is recommended to make an Integrated Transportation schedule. The results of the lowest recapitulation of connectivity during the COVID-19 pandemic in the statement of the overall time to reach the public transportation network is very short (less than 1 hour). Planning by arranging schedules for all mass transportation so that when passengers make interchange, they become well connected / connected could make it better.

The Effect of Accessibility and Connectivity on Service Quality during the COVID-19 pandemic shows the coefficient of determination value of 0.563 , so it can be interpreted that the effect of accessibility and connectivity on Service Quality (Y) is $56.3 \%$ with the remaining $43.7 \%$. The results of the lowest recapitulation of Service Quality during the COVID-19 pandemic is in the statement of the availability of roads or paths from origin to stop and from very many stops, it is recommended that the route or road be added.

\section{References}

Andriani, I. (2018). Integrasi Transportasi dalam Mendukung Kawasan Destinasi Wisata Tanjung Kelayang Kabupaten Belitung [Transportation Integration in Supporting the Tanjung Kelayang Tourism Destination Area, Belitung Regency]. Jurnal Transportasi Multimoda [Journal of Multimodal Transportation], 16 (01).

Chairi, M., Yossyafra, \& Putri, EE (2017). Perencanaan Integrasi Layanan Operasional antar moda Railbus dan Angkutan Umum di kota padang [Planning for Integration of Operational Services between Railbus and 
Public Transport modes in the city of Padang]. Jurnal Rekayasa Sipil [Journal of Civil Engineering] (JrsUnand), 13 (1), 1-12.

Irianto, R. P (2019). Integrasi Antarmoda Transportasi Massal Mudahkan Masyarakat [Integration of Mass Transportation Intermodals Facilitate the Citizens]. Megapolitan.

Kuswati, A. S (2012). Kriteria penetapan lokasi stasiun kereta api penumpang [Criteria for determining the location of a passenger train station]. Warta Penelitian Perhubungan [Transportation Research Newsletter], $24(5)$.

Laurentia. AN, \& Syafi'i. (2013). Pemodelan Pemilihan Moda Angkutan Antar Kota Bus Dan Kereta Api (Studi Kasus Bus Dan Kereta Api Jurusan Yogyakarta-Madiun) [Modeling of Intercity Bus and Train Mode Selection (Case Study of Yogyakarta-Madiun Department of Bus and Train)], (Warpani 1990), 30-37.

Ramadhan, GR, \& Buchori, I. (2018). Strategi integrasi sistem transportasi umum dalam menunjang pariwisata kota yogyakarta [Public transportation system integration strategy in supporting Yogyakarta city tourism]. Jurnal Pengembangan Kota [Journal of Urban Development], 7062 (1)

Rosada, RA, Purnomo, BA, \& Rahma, N. (2017). Integrasi Antar-Moda Pada Stasiun Universitas Indonesia Di Depok [Inter-Modal Integration At University Of Indonesia Railway Station In DEPOK]. Seminar Nasional Cendekiawan ke 3 [the 3rd National Scholarship Seminar] (pp. 173-182).

Sari, N. (2017). Bagaimana Cara agar Warga Beralih Gunakan Angkutan Umum? [How do you get residents to switch to using public transportation?]. Kompas.Com. Retrieved from https://megapolitan.kompas.com/read

Tjiptono Fandy. (2011). Management \&Strategi Merk [Brand Management \& Strategy]. Jogjakarta: Andi. 